UDC 378.091.313:811.111:378

DOI https://doi.org/10.24919/2308-4863/34-5-26

Iryna SHEVCHENKO,

orcid.org/0000-0001-6551-9266

Doctor of Philosophy in Education,

Associate Professor at the English Language and Literature Department

Mykolaiv V. O. Sukhomlynsky National University

(Mykolaiv, Ukraine) shevchenko2011@gmail.com

Olena KORDYUK,

orcid.org/0000-0003-2362-8557

Lecturer at the English Language and Literature Department Mykolaiv V. O. Sukhomlynsky National University (Mykolaiv, Ukraine) elena.kordyuk78@gmail.com

\title{
IMPLEMENTATION OF CLIL METHODOLOGY IN TEACHING PRACTICAL ENGLISH COURSE FOR THE 3RD YEAR STUDENTS OF PHILOLOGICAL FACULTIES AT HIGHER EDUCATIONAL ESTABLISHMENTS OF UKRAINE IN THE CONDITIONS OF DISTANT AND BLENDED LEARNING
}

Knowledge of a foreign language acquires fundamental and priority importance in today's globalization. Possessing integrated communication skills that provide professional and business relationships between people from different countries is becoming an obvious necessity for future foreign language professionals. Accordingly, special attention is paid at the present stage to the CLIL technique known in the world and actively used for effective foreign language learning.

The article is devoted to the problem of implementation of the methodology of content and language integrated learning (CLIL) in the process of studying the "Practical English Course" by 3rd year students of philological faculties of higher educational establishments of Ukraine with tests for independent work and self-control in blended and distant learning. Attention is paid to the effectiveness of testing and systematization of knowledge through this method during the study of the discipline. The purpose of the article is to highlight the main advantages of using the CLIL methodology in teaching the 3rd year students of the philological faculties of higher educational establishments of Ukraine in teaching the discipline "Practical English Course". Emphasis is made on the effectiveness of the use of tests for independent work and self-control, which give students the opportunity to test their knowledge of English in a blended and distant learning. The research emphasizes that the use of the CLIL methodology increases the motivation of students to learn English, promotes the development of their mental abilities, purposeful acquisition of lexical units and grammar knowledge, which will be used in their future professional activities.

Key words: content and language integrated learning, Practical English course, mixed learning, distant learning, future professional activity, test, independent work, self-control. 
Ірина ШЕВЧЕНКО,

orcid.org/ 0000-0001-6551-9266

доктор філософії в галузі освіти,

в. о. доцента кафедри англійської мови і літератури

Миколаївського начіонального університету імені В. О. Сухомлинського (Миколаїв, Україна) shevchenko2011@gmail.com

Олена КОРДЮК,

orcid.org/0000-0003-2362-8557

викладач кафедри англійської мови і літератури

Миколаївського національного університету імені В. О. Сухомлинського

(Миколаїв, Україна) elena.kordyuk78@gmail.com

\section{ІМПЛЕМЕНТАЦІЯ МЕТОДИТИКИ СLIL ПІД ЧАС ВИКЛАДАННЯ «ПРАКТИЧНОГО КУРСУ АНГЛІЙСЬКОЇ МОВИ» ДЛЯ СТУДЕНТІВ ІЗ КУРСІВ ФІЛОЛОГІЧНИХ ФАКУЛЬТЕТІВ ЗВО УКРАЇНИ В УМОВАХ ДИСТАНЦЙНОГО ТА ЗМІШАНИХ ФОРМ НАВЧАННЯ}

Знання іноземної мови набуває принципового та пріоритетного значення в сучасних умовах глобалізації. Володіння інтегрованими комунікативними навичками спілкування, щчо забезпечують професійно-діловий взаємозв'язок людей різних країн, стає очевидною необхідністю для майбутніх фахівців з іноземної мови. Відповідно, особливої уваги на сучасному етапі набуває методика clil, відома у світі і активно використовувана для ефективного вивчення іноземної мови.

Стаття присвячена розгляду проблеми імплементації методики предметно-мовного інтегрованого навчання (clil) у процесі вивчення «Практичного курсу англійської мови» студентами 3 курсу філологічних факультетів ЗВО Украӥни за допомогою тестів для самостійної роботи і самоконтролю в умовах змішаної та дистаниійноі форм навчання. Звернено увагу на ефективність перевірки і систематизації знань за посередництвом указаної методики під час вивчення навчальної дисиипліни. Метою статті є висвітлення основних переваг застосування методики clil упродовж вивчення студентами 3 курсу філологічних факультетів ЗВО Украӥни дисципліни «Практичний курс англійської мови». Підкреслюється ефективність використання тестів для самостійної роботи $і$ самоконтролю, щуо дають можливість студентам перевірити свої знання з англійської мови в умовах змішаної і дистаниійної форм навчання.

У розвідиі підкреслюється, щзо використання методики сlil підвищує мотивацію вивчення англійської мови у студентів, сприяє розвитку їх розумових здібностей, иілеспрямованому засвоєнню лексичних одиниць $i$ знань $з$ граматики, які використовуватимуть у своїй майбутній професійній діяльності.

Ключові слова: предметно-мовне інтегроване навчання, практичний курс англійської мови, змімана форма навчання, дистаниійна форма навчання, майбутня професійна діяльність, тест, самостійна робота, самоконтроль.

Problem statement. Modern educational life in Ukraine is a confirmation of the gradual process of integration into the European scientific and information space. The development and implementation of new computer technologies, the emergence of new gadgets requires future professionals not only to have integrated communication skills, which can provide professional and business communication between people of different countries, as well as knowledge of English lexical units for certain areas of production, human life, namely, education, medicine, art, etc.

The CLIL (Content and Language Integrated Learning) methodology acquires special attention in the context of functional mastering a foreign language and the principle of integration in this case.

Researcher David Marsh explains that the CLIL technique allows learners to develop foreign language linguistic and communicative competencies in the same learning context in which they develop general knowledge and skills. The use of the CLIL technique involves the study of non-linguistic subjects (biology, mathematics, geography, etc.) by foreign languages (Marsh, 2016).

Research analysis. Such scientists as S. Bobyl, Y. Rudnik, Y. Sobol, O. Khodakovska and others paid attention to the problem of subject-language integrated learning in their works.

Among foreign researchers of content and language integrated learning, such scholars as M. Allen, A. Bonne, D. Greddol, L. Collins, D. Marsh, I. Ting, and others should be singled out.

The purpose of the article. The main purpose of this work is to show the means of implementation of the CLIL methodology during the study of the discipline "Practical English Course" by 3rd year students of philological faculties of the higher educational 
establishments of Ukraine with tests for independent work and self-control in distance and blended learning.

Presenting the main material. Researcher O. Khodakovska believes that the study of language by the method of CLIL becomes more purposeful, because the language is used to solve specific communicative tasks. In addition, students have the opportunity to better understand and perceive the culture of the language being studied, which leads to the formation of socio-cultural competence of students.

A student or pupil passes through a fairly large amount of language material, which is a full immersion in the natural language environment. Working with different topics allows you to study specific terms, certain language structures, which helps to replenish the vocabulary of a student or pupil with subject terminology and prepares him for further study and application of knowledge and skills. The study of a foreign language and a non-language subject is both an additional means to achieve educational goals and has positive aspects for both the study of a foreign language and a non-language subject (Marsh, 2016).

Experience shows that the study of English by the method of CLIL creates the conditions for Ukraine's entry into the transcontinental system of computer information and is the basis for the emergence of a new system of information support for education.

As a result, the development of distant and blended learning is becoming extremely important.

Such scientists and practitioners as V. Dyvak, N. Dumansky, T. Kramarenko, V. Popov, V. Trohymenko and others paid attention to the issue of distant learning in the educational process of higher educational establishments.

According to the researcher V. Kukharenko, "distant learning" is learning by means of telecommunications, in which subjects (students, teachers, tutors) having a spatial or temporal distance, carry out a general educational process aimed at creating external educational products and relevant internal changes (increases) of subjects of study (Kukharenko, 2002).

Scientists V. Kukharenko, O. Rybalko, N. Sirotenko point out that distant learning is carried out only with the help of the Internet, because the receipt of educational materials and tasks, and all other issues related to communication, are only in absentia. Intermediate and final certification is also carried out by sending and checking materials (Kukharenko, 2002).

In this regard, according to the scholars, the following negative factors of distant learning become apparent, namely: the lack of face-to-face communication between a teacher and a student, which does not allow to implement an individual approach to teaching and education; students are not always self-disciplined, conscious and independent; lack of good technical equipment for constant access to information sources; lack of practical training and lack of constant control (Kukharenko, 2002).

Experience, practice and a large amount of modern research indicate that in this case it is necessary to use a blended form of learning that creates a comfortable educational information environment, and communication systems provide all the necessary educational information.

According to the scientist A. Andreev, blended learning should be understood as combining traditional teaching methods with interactive ones, which consists of three stages: distant learning of theoretical material, mastering practical aspects in the form of full-time classes, the last phase - passing an exam or completion of graduation paper (Andreyev, 2007).

The scholar explains that in blended learning elements of asynchronous and synchronous distance learning are used, the essence of which is that a certain part of academic disciplines (or disciplines) students (students) learn in traditional forms of education (full-time or part-time, etc.), and another part of disciplines (or discipline) - by network learning technologies. The ratio of parts is determined by the readiness of the educational institution as a whole to such a construction of the educational process, as well as the desire and technical capabilities of students (listeners). This approach is called "flexible learning" (Andreyev, 2007).

Analysis of the curriculum for «Practical English course» specialty 014.02 Secondary education. Language and literature (English) for the 3rd year students show that the ratio of classroom hours and hours for independent work is approximately $40 \%$ : $60 \%$. Thus, in the first semester of the "Practical English course" specialty 014.02 Secondary education. Language and literature (English) for the 3 rd year provides 50 hours of classroom classes and 90 hours of independent work. In the second semester, 66 hours of classroom classes and 144 hours of independent work.

The program "Practical English Course" for the 3rd year students provides for the study of certain topics in grammar, which give students the opportunity to test their knowledge in English. These are the topics: "The Article", "The Adjective", "The Adverb", "Passive voice", "Sequence of Tenses", "Indirect speech".

Experience and practice show that students make the most mistakes on topics such as "The Article", "The Adjective", "The Adverb".

In order to test knowledge and identify errors, students can be offered the following tests on the topic of "The Article": 
TEST 1.

Task 1. Choose the correct answer.

1. Queen Mary is docked in Beach in California.
A) The,-,-
B) A, an,-
C) An,--, the
D)-,-, the

2. It was thought it was second chance of hers and she
A) An, an
B) A, a
C) The, the
D)-,-

3. Savoy and beat one.

world famous chain hotels.
A) An, a, -
B) The, the, the
C) A,-, an
D)-,-, the
4. Would you like give me bit.
A) A, a
B) An, an
C)-, -
D) The, the
5. Walter is having broccoli for dinner.
A) The, the
B)-,-
C) An, an
D) A, a
6. During Renaissance chicken and tuna sandwich? - Yes, inventions were made.
A) The, a
B) A, the
C) -, an
D) -, the
7. Mars, and Venus and

Earth are the planets of the solar system.
A) An, an, a
B) The, the,-
C) A, a, the
D),,-- the

8. official language of Ukraine is

Ukrainian language.
A) A, the
B) A,-
C)-, the
D) The, the

9. World Court is situated in Hague in Netherlands.
C) An ,an, an

D) The, the, the

Long 10. His cats name is Pussy. What for cat! name

A)-,-

B) An, an

C) A, a

D) The, the

11. Most of all I love Strauss waltz is very sweet. waltzes and

A) The,-

B)-, a

C) An, the

D) The, a

12. That was most famous song of most popular and
A) The, the, the
B) An, an, an
C)-,-,-
D) A, a, a
13. We worked for year at United Nations.
A) The,-
B) A, the
C)-, a
D) The, a

14. last president of Soviet Union M. Gorbachov was awarded Nobel Prize.
A) An, the,-
B) -, the, an
C) The, the, the
D) A, an, the lot of

15 . Oxford University is one of oldest universities in the world.

A)-, the

B) The, the

C) A,-

D) An, the

Task 2. Choose the correct answer.

1. They looked at only woman in the room who was sitting near
A) An, the
B)-, a
C) The, the
D) An, the
2. If you have and drink

A) The, the, a, the

B) An, the, -,-

C)- Ithe, a,-,-

D) The,-, a,-

3. Which desert is larger, fireplace.

Desert or Kara Kum Desert? Sahara 
A)-, the, the

B) A, a, the

C) The,-,-

D) An,-, the

4. During that accident all taken to
A) An, an
B)-,-
C) The, the
D) A, A
5. When I came nearest hospital. injured were me that idea who he is.
A) An,-, a
B) The, an,-
C) The, an, a
D)-,-,-
6. There are some charity programs for poor in Kyiv City Council.
A)-
B) The
C) An
D) A

7. highest mountains in Ukraine are Carpathians.
A) An, the, a
B) A, an,-
C)-, the, a
D) The,-, the

8.

Hermitage was most famous museums in one of Soviet

\section{Union.}
A) The,-, the, the
B)-, a, an, the
C)-, a, an,-
D) An, the, -, a
9. Greens left for spring of 1997.
A) The,-, the
B) A, the, an
C) An,-, the
D)-, the, a
10. Our students always read at their English lessons.

Economists
A) The,-
B) A, the
C) An,-
D)-, an
11.

Ivan Franco Theatre in is national pride of Ukraine. America in
A)-, the,-
B) A, an,-
C) -, -, the
D) An, the,-

12. When Thomas was in Netherlands he visited Hague.
A) A, a
B)-,-
C) An, an
D) The, the

13.

Baikal is fresh water in largest lake with

A) An,-, the, a

B)-,-, a,-

C) A, the,-, an

D) The, the,-, the

14. Ben Nevis is in Highlands in highest peak
A) A, an,-,-
B)-, the, the,-
C) An, the,-, an
D) The, the, the, the

15. Richard

England in Lionheart lived in
A) The,-, the
B) A, the,-
C) An, a, the
D) -, the, a

З теми "The Adjective" ми пропонували такі тести:

\section{TEST 1.}

Task 1. Choose the correct answer.

1. The old road is of the new one.
A) one third as long

B)three times as short

C) one third the length

D) three times of size

2. The dolphin is than the shark.
A) more intelligent
B) intelligetier
C) the most intelligent
D) intelligent

3. Hugh is his elder brother.
A) the clever as
B) as clever as
C) not clever as
D) so clever as

4. Greg is
A) tired
B) the most tired
C) more tired
D) tireder

5.

A) The much, the much

B) The many, the many

C) The most, the most

D) The more, the more

6. Mark was so body told him about it. 

A) impolite
B) politeless
C) politely
D) politer
7. The castle was (a, an)
A) nice stone old
B) stone old nice
C) nice old stone
D)Old nice stone

8. The old lane was
A) narrower
B) narrow
C) narrowest/most narrow
D) the narrowest/the most narrow

9. It was day of the year. It had been raining so heavily for a week.
A) the wettest
B) wetter
C) wetty
D) wet
10. Sarah's

A) three year older

B) three year's old

C) three year old

D) three years old

11. Jupiter is
A) larger
B) large
C) more large
D) the largest
12. Mountain McKinley is planet of the solar system. in the USA. boy was so naughty
A) so high
B) as high
C) the highest
D) higher
13. The new house is
A) twice as both
B) twice as many
C) twice as more
D) twice as much
14. The room is
A) half as much
B) half the size
C) half as size
D) half the bigger

15. Sally was wearing a
A) gold
B) golded
C) golden
D) goldy

Task 2. Choose the correct answer.

1. Mr. Chilver told us it was his life. mountain
A) worse
B) the worst
C) badder
D) bad
2. Frank was not
A) as tall so
B) so tall as/as tall as
C) twice as tall all
D) so as tall
3. The weather seems to be this year than it was two years ago.
A) the most pleasant/ pleasantest
B) pleasant
C) more pleasant/ pleasanter
D) pleased

4. Ann's son is
A) as funny as
B) funny as
C) funny so
D) so funny

5. Mark's advice is: never buy any cars.
A) second hand's
B) a second hands
C) used
D) the second hand

6. we earn
A) The most, the most
B) The more, the more
C) Much, much
D) More, more

7. All the houses in this area are of the new ones.
A) one third the height
B) a three a height
C) thee times as low
D) one three the height
8. Mrs. Easton bought a building last week.
A) hundred years old
B) hundredth year old
C) hundred year older
D)hundred year old

9. Arlene is child in the family.
A) older
B) elder
C) the oldest
D) the eldest
10. Sheila spoke
A) so friendly
B) more friendly/ friendlier
C) the friendliest
D) friendly

11. The fishing rod I needed was previous one. 

A) twice as long
B) twice the length
C) twice the longer
D) two as long
12. Tom says it's unbearable.
A) hotter
B) more hotter
C) hot
D) the hottest
13. Pluto is

A) more far

B) farther

C) the farthest

D) far

14. Diana looked at the tablecloth and sighed.

A) candle-stick
B) candlelight

C) candle lighted

D) candle-lit

15. I know you are

A) more interested

B) the most interested

C) most interested

D) interested (Shevchenko, 2020)

Conclusions. The modern CLIL technique has obvious advantages in the process of learning a foreign language. It motivates students to learn, encourages meaningful memorization of new lexical items and learning grammar rules. The use of tests for independent work and self-control provides students in the conditions of blended and distant learning forms to test and deepen their knowledge of lexical units and grammar rules that they will apply in their future professional activities.

\section{BIBLIOGRAPHY}

1. Андреев А. УМК для е-Learning. Высшее образование в России. 2007. № 7. С. 65-69.

2. Marsh D. Content and Language Integrated Learning: The European Dimension - Actions, Trends and Foresight Potential. URL : http://europa.eu.int/comm/education/languages/index/html (дата звернення: 14.09.2019).

3. Кухаренко В. Дистанційне навчання: Умови застосування. Дистанційний курс : навч. посіб. / В. М. Кухаренко, О. В. Рибалко, Н. Г. Сиротенко. Харків : НТУ «ХПІ», «Торсінг», 2002. 320 с.

4. Ходаковська О. Особливості методики предметно-мовного інтегрованого навчання. URL : https://conf.ztu.edu.ua/ wp-content/uploads/2016/11/63.pdf (дата звернення: 12.09.2020).

5. Шевченко I. В. Навчально-методичний посібник із «Практичного курсу основної мови» для студентів 3 курсу. Лексико-граматичні завдання для самостійної роботи і самоконтролю. Миколаїв : МНУ імені В.О. Сухомлинського, 2020. $160 \mathrm{c}$.

\section{REFERENCES}

1. Andreyev A. UMK dlya e-Learning. [TMC for e-Learning]. Higher education in Russia. 2007, № 7, pp. 65-69 [in Russian].

2. Marsh D. Content and Language Integrated Learning: The European Dimension-Actions, Trends and Foresight Potential. Retrieved from http://europa.eu.int/comm/education/languages/index/html. [in English].

3. Kukharenko V. Dystantsiyne navchannya: Umovy zastosuvannya. Dystantsiynyy kurs: navch. posib. [Distance learning: The conditions of use. Distance course: textbook]. Kharkiv: STU "HPI", "Torsing", 2002. 320 p. [in Ukrainian].

4. Khodakovska O. Osobly'vosti metody 'ky' predmetno-movnogo integrovanogo navchannya. [Peculiarities of methodology of content and language integrated learning]. Retrieved from: https://conf.ztu.edu.ua/wp-content/uploads/2016/11/63. pdf. [in Ukrainian].

5. Shevchenko I.V. Navchal'no-metodychnyy posibnyk iz «Praktychnoho kursu osnovnoyi movy» dlya studentiv 3 kursu. Leksyko-hramatychni zavdannya dlya samostiynoyi roboty i samokontrolyu. [Training manual "Practical English Course" for the 3rd year students. Lexical and grammatical exercises for independent work and self-control]. Mykolaiv: V.O. Sukhomlynsky National University, 2020. 160 p. [in Ukrainian]. 